УдК 343.98

\author{
С. М. Поліщук, О. А. Самойленко
}

\title{
СПОСОБИ ВЧИНЕННЯ НЕЗАКОННИХ ДІЙ ЩОДО МАЙНА, НА ЯКЕ НАКЛАДЕНО АРЕШТ, ЗАСТАВЛЕНОГО МАЙНА АБО МАЙНА, ЯКЕ ОПИСАНО ЧИ ПІДЛЯГАЄ КОНФІСКАЦІЇ
}

Постанова проблеми. Наявний стан розслідування незаконних дій щодо майна, на яке накладено арешт, заставленого майна або майна, яке описано чи підлягає конфіскації, вимагає теоретичного та методичного супроводження процесу розслідування таких кримінальних правопорушень. Адже протягом останніх п'яти років при зменшенні в середньому кількості осіб, які засуджені за вчинення цього кримінального правопорушення, кількість самих правопорушень має стійку тенденцію до зростання (2013 p. - 681; 2014 p. - 559; 2015 p. - 822; 2016 p. - 841) [1].

Аналіз останніх досліджень і публікацій. Проблемам кваліфікації вказаного злочину присвячені роботи О.О. Дудорова, М.І. Омельяненко, B.I. Осадчого, О.О.Соболевої [2; 3]. У криміналістичному аспекті незаконні дії щодо майна, на яке накладено арешт, заставленого майна або майна, яке описано чи підлягає конфіскації, розглядались А.П. Мазур, С.О. Книженко щодо криміналістичної класифікації злочинів проти правосуддя [4; 5]. Але досі в юридичній літературі не знайшли широкого висвітлення теоретичні засади розслідування названих злочинів, зокрема й способи їх учинення. Адже саме останні $є$ центральним моментом у генезисі злочинної поведінки суб'єкта злочину [6, с. 107].

Тому метою статті $€$ визначення способів учинення незаконних дій щодо майна, на яке накладено арешт, заставленого майна або майна, яке описано чи підлягає конфіскації.

Виклад основного матеріалу дослідження. Більшість криміналістів пристали до концепції Р.С. Бєлкіна, М.П. Яблокова, які під способом учинення злочину розуміли об'єктивно й суб'єктивно зумовлену систему поведінки суб'єкта до, у момент і після вчинення злочину, що залишає різного роду характерні сліди зовні, які дають змогу за допомогою криміналістичних прийомів і засобів одержати уявлення про сутність того, що відбулось, своєрідність злочинної поведінки правопорушника, його окремі особистісні дані $[7$, с. 16]. Отже, в криміналістичному аспекті способи злочину будуть визначатися сукупністю ознак, що характеризують своє- 
рідність певного етапу злочинної поведінки правопорушника, його окремі особисті дані, які впливають на обрання відповідного предмета злочину та способу дії, поширеність останнього. Ці ознаки мають суто криміналістичне значення: необхідні для висунення версій, пошуку слідів, виявлення причин і умов, що сприяли вчиненню злочину, відповідно, забезпечення якості профілактичної діяльність слідчого.

У криміналістичній науці про окремі способи незаконних дій щодо майна, на яке накладено арешт, заставленого майна або майна, яке описане чи підлягає конфіскації, велась мова під час дослідження злочинів проти власності (Н.В. Павлова, Т.А. Пазинич) або економічних злочинів (Т.В. Охрімчук, О.В. Курман, В.В. Білоус) [8-12]. Так, Н.В. Павлова серед способів учинення шахрайства, пов'язаного з відчуженням приватного житла, називає продаж житла, яке має юридичні обмеження або невиконані зобов'язання, зокрема коли таке житло арештоване або передано в заставу $[13$, с. 51$]$. Продаж або інші способи реалізації заставленого майна розглядають одним із етапів способу вчинення шахрайства з фінансовими ресурсами. Тож системного уявлення про способи вчинення незаконних дій щодо майна, на яке накладено арешт, заставленого майна або майна, яке описане чи підлягає конфіскації, досі немає.

У ст. 388 Кримінального кодексу (далі - КК) України чітко визначені діяння об’єктивної сторони незаконних дій щодо майна, на яке накладено арешт, заставленого майна або майна, яке описане чи підлягає конфіскаціï, а саме: 1) розтрата, 2) відчуження, 3) приховування, 4) підміна, 5) пошкодження, 6) знищення, 7) порушення обмеження права користування таким майном; 8) здійснення операцій із коштами (вкладами), на які було накладено арешт; 9) інші незаконні дії з таким майном.

Як і в кримінальному праві, наведені діяння в криміналістиці будуть виступати формами незаконних дій із майном особливого правового статусу, вони в загальному зовнішньому вигляді характеризують зазначений злочинний вияв. Кожна з наведених форм незаконних дій щодо майна, на яке накладено арешт, заставленого майна або майна, яке описане чи підлягає конфіскації, може вчинюватися різними способами, пряма вказівка на які в кримінальному законі відсутня. Визначити типові способи кожної з форм досліджуваних незаконних дій дає можливість узагальнення матеріалів судово-слідчої практики. Однак підкреслимо, що пі час дослідження способів безпосереднього вчинення зазначеного злочину ми будемо спиратися на результати докладного кримінально-правового аналізу зазначених форм (у роботах О.О. Дудорова, М.I. Омельяненко, О.О. Соболєвої, М.I. Панова, П.С. Матишевського, М.І. Мельника).

Розтратою в кримінальному праві прийнято вважати протиправну витрату винним майна, що було йому ввірене або перебувало в його віданні, у своїх корисних інтересах або в інтересах іншої особи [14, с. 317; 15 , с. 508]. Опускаючи ознаку безоплатності, розтратою арештованого, описаного, заставленого майна або майна, що підлягає конфіскації, вважають протиправне відчуження, витрачення або споживання винним майна, 
що має відповідний правовий режим (продаж, дарування, обмін, уживання в їжу, використання речей, які швидко зношуються, тощо) [3, с. 116]. Проведений нами аналіз фабул кримінальних правопорушень, зареєстрованих за ст. 388 КK України, протягом 2012-2016 рр. (за відомостями Національної поліції України в ІПС «Кримінальна статистика») свідчить, що способами безпосереднього вчинення розтрати майна $€$ його споживання (для опалення, для ведення сільського господарства, вживання в їжу), передача за рахунок сплати інших наявних боргів.

Відчуження майна, по суті, є формою розтрати й означає, що майно на оплатній чи безоплатній основі передається у володіння іншим особам, до яких переходить право власності на це майно [15]. Серед відомостей ІПС «Кримінальна статистика» містяться такі способи вчинення відчуження майна особливого правового статусу: продаж, дарування, міна, довіреність на розпорядження майном із наступним оформленням у власність іншої особи. Способами підготовки є діï, спрямовані на пошук покупця (надання оголошення про продаж або обмін), місця для укладання угоди, нотаріуса тощо. Але більш поширеними способами підготовки та приховування таких незаконних дій із майном особливого правового статусу є службові підроблення, обман чи зловживання довірою, вчинення інших злочинів, які спрямовані на створення умов для кінцевої дії з відчуження майна.

Приховування майна розуміється як його утаювання будь-яким чином від певних органів або осіб [3, с. $118 ; 16$, с. $967 ; 17$, с. $288 ; 18$, с. 302]. Таке приховування майна здійснюється шляхом зберігання в схованках, зміни зовнішнього вигляду майна, ідентифікаційних його ознак, передачі для зберігання іншим особам тощо. При цьому злочинець може створювати умови чи речовинну обстановку, яка буде вказувати на відсутність майна в зберігача: імітувати крадіжку, пожежу, затоплення, аварію.

Виходячи з аналізу розгорнутих фабул досліджуваного злочину, що містяться в ІПС «Кримінальна статистика», визнаємо, що більшість $(95 \%)$ незаконних дій щодо майна, на яке накладено арешт, заставленого майна або майна, яке описане чи підлягає конфіскації, заявлені як учинені способами приховування цього майна, не підтверджуються під час досудового розслідування. Провадження закриваються за п. 2 ч. 1 ст. 284 Кримінального процесуального кодексу України як такі, в яких установлена відсутність у діянні складу кримінального правопорушення. Це пояснюється тим, що за умови, коли кредитор чи державний виконавець із різних причин не може потрапити на місце зберігання майна та перевірити його наявність, передчасно робиться висновок про приховування його зберігачем. Доходимо думки, що судову перспективу отримають тільки кримінальні провадження, які відкривались за заявами з деталізацією способів приховування майна.

Підміна є різновидом приховування майна, оскільки здійснюється саме із цією метою. Як правило, описане, заставлене або арештоване майно, що має більшу економічну цінність, підмінюється майном меншої цінності. Серед усього аналізованого матеріалу судово-слідчої практики помічено лише одиничні випадки підміни майна особливого правового статусу. Так, 
K. з метою залишення у своєму господарстві описаного та арештованого автомобіля ГАЗ-САЗ-3507 підмінив на ньому кабіну з іншого, не описаного й арештованого автомобіля ГАЗ 53 Б 1980 року випуску, внаслідок чого позбавив стягувача, а саме ВАТ АКБ «Надра», можливості відшкодування заподіяних унаслідок неналежного виконання договірних зобов'язань збитків за рахунок заставленого для одержання кредиту майна [19].

Пошкодження та знищення є близькими за змістом формами незаконних дій із майном особливого правового статусу. Якщо пошкодження розуміється як утрата матеріальної цінності майна, то знищення майна це приведення його в повну непридатність для подальшого використання згідно із цільовим призначенням [2, с. 101]. Аналіз фабул досліджуваного злочину, що містяться в ІПС «Кримінальна статистика», свідчить про те, що повністю або частково майно особливого правового статусу втрачає свою цінність шляхом його демонтування або розукомплектування, різних способів його утилізації. Як правило, за умови відсутності в злочинній діяльності ознак обману чи зловживання довірою незаконні дії шляхом демонтування або розукомплектування майна виконують одночасно й роль способів підготовки до відчуження нерухомого майна або транспорту.

Порушення обмеження права користування таким майном. Як ми вже наголошували вище, власник майна може бути не лише обмежений у праві розпорядження належним йому майном, а й у праві користуванні ним. На думку I.I. Давидович, О.О. Дудорова, порушення обмеження права користуватися майном може мати місце лише у випадках, коли таке обмеження прямо встановлено державним виконавцем [3, с. 121; 20, с. 476]. М.І. Омельяненко робить висновок, що із законодавчої конструкції «порушення обмеження (обтяження) права користуватися таким майном», а також назви ст. 388 KK України «Незаконні дії щодо майна, на яке накладено арешт, заставленого майна або майна, яке описано чи підлягає конфіскації випливає, що в них ідеться не про будь-які обмеження чи обтяження права користування майном, а лише про обмеження та обтяження користування, які було встановлено на майно в процесі (або в результаті) його арешту, опису, застави чи конфіскації [3, с. 122].

Систематизація таких обмежень права користування не має практичного сенсу. Аналіз фабул досліджуваного злочину, що містяться в ІПС «Кримінальна статистика», дає змогу лише визначити поширені способи порушення обмеження права користування майном: порушення накладеної заборони використовувати транспортний засіб; здавання в оренду майна без відповідної згоди кредитора; передавання майна на баланс іншого суб'єкта; без згоди податкової інспекції проведення операцій суб'єкта з коштами, що знаходяться в податковій заставі.

Здійснення операцій із коштами (вкладами), на які було накладено арешт. Відповідно ст. 59 Закону України «Про банки і банківську діяльність», за постановою державного виконавця, приватного виконавця чи рішенням суду про стягнення коштів або про накладення арешту банк зупиняє видаткові операції за рахунками юридичних, фізичних осіб або за 
власними рахунками [21]. Отже, як справедливо зазначають фахівці з кримінального права, у ст. 388 КK України йдеться виключно про видаткові банківські операції [2, с. 124; 3, с. 105]. Тому такі видаткові операції з арештованими коштами (вкладами), як переведення грошей на інші рахунки, оплата товару або послуг за різними угодами, їх інвестування, виконують роль способів безпосереднього вчинення злочину.

Інші незаконні дії з таким майном охоплюють способи вчинення злочину, що не утворюють вищеназвані форми дій із майном особливого правового статусу. Дійсно, надати вичерпний перелік форм і, відповідно, способів незаконної дії з майном особливого правового статусу неможливо. Системоутворювальним компонентом криміналістичної характеристики досліджуваного виду злочинів є предмет злочинного посягання. Останній характеризується різноманіттям фізичних властивостей і певним видом обтяження, що зумовлюють відповідний спосіб учинення 3 ним незаконних дій. До того ж злочинці можуть удосконалювати наявні способи вчинення злочину, враховуючи нові законодавчі ініціативи в державі. Так, у 2016 році серед відомостей ІПС «Кримінальна статистика» за ст. $388 \mathrm{KK}$ України можна зустріти фабули злочину щодо незаконного зняття заборони на відчуження майна.

Висновки. Отже, в результаті аналізу статистичних показників за 20122016 роки стосовно зареєстрованих за ст. 388 КК України кримінальних правопорушень (за відомостями Національної поліції України в ІПС «Кримінальна статистика») вважаємо доцільним виділити за специфікою структури способу вчинення злочину два різновиди досліджуваної злочинної діяльності:

1. Прості незаконні дії щодо майна, на яке накладено арешт, заставленого майна або майна, яке описане чи підлягає конфіскації, що кваліфікуються лише за ознаками ст. 388 КК України (20\%). Безпосередні способи ix учинення визначені через вищезазначені форми. Способи підготовки або взагалі відсутні, або полягають у простих організаційних діях (розукомплектувати, дати оголошення про продаж, знайти місце зберігання транспортного засобу тощо). Способи приховування в більшості таких злочинів відсутні. Як виняток на практиці може мати місце ситуація, коли цілі приховання на початку злочинної дії не переслідувалися, тоді спосіб приховання може існувати самостійно як система дій зі знищення, маскування або фальсифікації слідів злочину та злочинця [22, с. 735]. Виходячи з конкретних способів приховування, останній злочин можна буде розглядати як складний.

2. Складні незаконні дї щодо майна, на яке накладено арешт, заставленого майна або майна, яке описане чи підлягає конфіскації $(80 \%)$. Ці злочини пов'язані з учиненням на етапі підготовки чи приховування інших кримінальних правопорушень, спрямованих на усунення фактичних перешкод для вчинення дії, форми якої передбачені ст. $388 \mathrm{KK}$ України, на створення передумови для цього. Це, відповідно, позначається на кваліфікації зазначеного злочину, яка здійснюється за сукупністю статей КК України. 
Наприкінці зазначимо, що для отримання максимально повного, типового уявлення про способи вчинення незаконних дій щодо майна, на яке накладено арешт, заставленого майна або майна, яке описане чи підлягає конфіскації, потрібно використовувати саме системний підхід. Систематизація безпосередніх способів учинення злочину, передбаченого ст. 388 KK України, дасть змогу визначити надалі типовість їх зв'язку з іншими злочинними виявами. Це $є$ необхідною умовою розроблення відповідних криміналістичних рекомендацій із їх розслідування.

\section{Література}

1. Статистична інформація Генеральної прокуратури України [Електронний ресурс]. Режим доступу : http://www.gp.gov.ua/ua/stat.html.

2. Соболева О.О. Кримінальна відповідальність за незаконні дії щодо майна, яке накладено арешт, заставленого майна або майна, яке описано чи підлягає конфіскації : дис. ... канд. юрид. наук : спец. 12.00 .08 «Кримінальне право та кримінологія; кримінально-виконавче право»; О.О. Соболева. - Луганськ, 2012. - 226 с.

3. Омельяненко M.I. Кримінально-правова охорона порядку поводження з майном, на яке накладено арешт або яке описано чи підлягає конфіскації : дис. ... канд. юрид. наук : спец. 12.00.08 «Кримінальне право та кримінологія; кримінально-виконавче право» M.І. Омельяненко. - Запоріжжя, 2011. - 232 с.

4. Мазур А.П. Побудова криміналістичних версій на початковому етапі розслідування / А.П. Мазур / / Право і суспільство. - 2015 . - № 4/2. - С. 193-198.

5. Книженко С.О. Криміналістична класифікація злочинів проти правосуддя / С.О. Книженко // Право і безпека. - 2013. - № 1 (48). - С. 113-117.

6. Прикладная юридическая психология : [учебное пособие для вузов] / под ред. проф. А.М. Столяренко. - М. : ЮНИТИ-ДАНА, 2001. - 639 с.

7. Яблоков Н.П. Криминалистика / Н.П. Яблоков. - М. : Изд. группа НОРМА-ИНФРА, 2000. -384 c.

8. Павлова Н.В. Особливості розслідування шахрайства, пов'язаного з відчуженням приватного житла : автореф. дис. ... канд. юрид. наук : спец. 12.00 .09 «Кримінальний процес та криміналістика; судова експертиза» / Н.В. Павлова. - Д., 2007. - 21 с.

9. Пазинич Т.А. Криміналістична характеристика шахрайств та основні положення їх розслідування : автореф. дис. ... канд. юрид. наук : спец. 12.00.09 «Кримінальний процес та криміналістика; судова експертиза» / Т.А. Пазинич. - Х., 2007. - 20 с.

10. Охрімчук Т.В. Криміналістична характеристика шахрайства з фінансовими ресурсами та основні напрями розслідування : автореф. дис. ... канд. юрид. наук : спец. 12.00 .09 «Кримінальний процес та криміналістика; судова експертиза; оперативно-розшукова діяльність» / T.В. Охрімчук. - K., 2011. - 16 с.

11. Курман О.В. Методика розслідування шахрайств з фінансовими ресурсами : автореф. дис. ... канд. юрид. наук : спец. 12.00.09 «Кримінальний процес та криміналістика; судова експертиза» / О.В. Курман. - Х., 2002. - 19 с.

12. Білоус В.В. Проблеми методики розслідування фіктивного підприємництва : автореф. дис. ... канд. юрид. наук : спец. 12.00.09 «Кримінальний процес та криміналістика; судова експертиза» / В.В. Білоус. - Х., 2004. - 20 с.

13. Павлова Н.В. Особливості розслідування шахрайства, пов'язаного з відчуженням приватного житла : дис. ... канд. юрид. наук : спец. 12.00.09 «Кримінальний процес та криміналістика; судова експертиза» / Н.В. Павлова. - Дніпропетровськ, 2007. - 224 с.

14. Кримінальне право України: Особлива частина : [підручник для студентів юрид. вузів і фак.] / [Г.В. Андрусів, П.П. Андрушко, С.Я. Лихова та інші] ; за редакцією П.С. Матишевського та інших. - К. : Юрінком Інтер, 1999. - 896 с.

15. Науково-практичний коментар Кримінального кодексу України / [А.М. Бойко, Л.П. Брич, В.К. Грищук та ін.] ; за ред. М.І. Мельника, М.І. Хавронюка. - 7-е вид., переробл. і допов. - К. : Юридична думка, 2010. - 1288 с.

16. Уголовный кодекс Украины. Научно-практический комментарий / [Ю.В. Александров, П.П. Андрушко, В.И. Антипов и др.] ; отв. ред. С.С. Яценко. - 3-е изд., исправл. и дополн. K. : A.C.K., 2005. - 1091 c. 
17. Преступления против правосудия / [А.Н. Александров, Ю.И. Антонов, А.В. Галахова и др.] ; под ред. А.В. Галаховой. - М. : Норма, 2005. - 416 с.

18. Кузнєцов В.О. Кримінальне право України. Загальна та Особлива частини : [навчальний посібник] / В.О. Кузнєцов, М.П. Стрельбицький, В.К. Гіжевський. - К. : Істина, 2005. - 380 с.

19. Вирок по справі № 1-38/2008-р від 18 квітня 2008 року Теребовлянського районного суду Тернопільської області / / Єдиний державний реєстр судових рішень [Електронний ресурс]. - Режим доступу : http:/ / www.reyestr.court.gov.ua/Review/1833092.

20. Науково-практичний коментар до Кримінального кодексу України : у 2 т. / [П.П. Андрушко, Т.М. Арсенюк, О.Ф. Бантишев та ін.] ; за заг. ред. П.П. Андрушка, В.Г. Гончаренка, Є.В. Фесенка. - 3-тє вид., переробл. та допов. - К. : Алерта ; КНТ ; Центр учбової літератури, 2009. - T. 2. - 2009. -624 c.

21. Про банки і банківську діяльність : Закон України від 07.12.2000 № 2121-III [Електронний ресурс]. - Режим доступу : http:/ / zakon2.rada.gov.ua/laws/show/2121-14/page.

22. Белкин Р.С. Курс криминалистики : [учебное пособие для вузов] / Р.С. Белкин. 3-е изд., доп. - М. : ЮНИТИ-ДАНА, 2001. - 837 с.

\section{А нот а ц і я}

Полішук С. М., Самойленко О. А. Способи вчинення незаконних дій щодо майна, на яке накладено арешт, заставленого майна або майна, яке описано чи підлягає конфіскації. - Стаття.

Стаття присвячена висвітленню способів учинення незаконних дій щодо майна, на яке накладено арешт, заставленого майна або майна, яке описано чи підлягає конфіскації. Такі способи систематизовані, в результаті чого визначено два різновиди досліджуваної злочинної діяльності.

Ключові слова: арештоване майно, заставлене майно, майно, що підлягає конфіскації, механізм злочину, описане майно, спосіб учинення злочину.

\section{Анно т а ция}

Полищук C. H., Самойленко O. A. Способы совершения незаконных действий в отношении имущества, подвергнутого аресту, заложенного имущества или имущества, которое описано или подлежит конфискации. - Статья.

Статья посвящена освещению способов совершения незаконных действий в отношении имущества, подвергнутого аресту, заложенного имущества или имущества, которое описано или подлежит конфискации. Данные способы систематизированы, в результате чего определены две разновидности структуры исследуемой преступной деятельности.

Ключевые слова: арестованное имущество, заложенное имущество, имущество, которое подлежит конфискации, механизм преступления, описанное имущество, способ совершения преступления.

\section{S u m m a r y}

Polishchuk S. M., Samoilenko O. A. Modus of illegal actions with property which is under arrest, foreclosed property, and property which has been inventoried or is to be forfeited. - Article.

The article is devoted to illumination of methods of accomplishing of illegal actions with property which is under arrest, foreclosed property, and property which has been inventoried or is to be forfeited. The given methods are systematized, two varieties of structure of the explored criminal activity are certain as a result.

Key words: prisoner property, property stopped up, property which is subject to confiscation, mechanism of crime, described property, modus of crime. 